\title{
Brazil to investigate if other factors act with Zika to cause congenital defects
}

\author{
Cláudia Collucci
}

São Paulo

The Brazilian government has launched an investigation to find out if factors other than Zika virus disease were involved in the development of microcephaly in some fetuses after noting an uneven distribution of cases across the country.

In spring this year the WHO and the US Centers for Disease Control and Prevention announced that Zika infection during pregnancy was linked with microcephaly as well as congenital blindness, stillbirth, and other fetal abnormalities. ${ }^{12}$ The acknowledgement came a year after the first case of Zika infection was confirmed in Brazil.

But scientists in Brazil have been puzzled by the fact that cases of congenital Zika syndrome have clustered in the north east part of the country, and that the expected surge in cases elsewhere in the country has not happened.

Of the 1749 confirmed cases of microcephaly or other central nervous system birth defects, $85 \%$ were concentrated in the north east, according to a report by the ministry of health, released in late July. ${ }^{4}$ A fifth of confirmed cases (376) were in Pernambuco state, in the north east of Brazil.

The country's second most populated state, Minas Gerais, in east central Brazil, has recorded just four cases of malformation from Zika virus infection while São Paulo, the most populated state, has confirmed just 11 cases.

Fatima Marinho, coordinator of epidemiological analysis and information at Brazil's ministry of health, said that the data suggested that there may be other factors at play. "We started to think that in this area [northeast] maybe something more than Zika is causing this intensity and severity. We're not ruling anything out," she said.

If the Zika virus was the only cause, then cases of microcephaly would have grown at the same rate throughout the country, she said.

Marinho told The $B M J$ that the ministry was creating a database of information about the families affected by microcephaly in collaboration with the London School of Hygiene and Tropical Medicine and the Institute for Health Metrics and Evaluation in Seattle.
"We hope this population analysis will enable us to give a direction to our work," she said.

Alexandre Chiavegatto Filho, a professor of health statistics at the University of São Paulo, said that Brazil and the rest of the world needed to do more research on this topic. "There's a lot that we still don't know about this association," he said.

One possibility was that poor hygiene could be a risk factor. More than $70 \%$ of women who have had babies with microcephaly were poor, young, and lived in small cities or on the outskirts of big ones.

Esper Kallas, a professor at the University of Sao Paulo, suggested that co-infections of Zika and other flaviviruses, such as dengue, might be interacting to cause the high rate of birth defects in the north east.

Another theory is that bovine viral diarrhoea virus (BVDV) may be implicated. Adriana Melo and her colleagues at the Federal University of Rio de Janeiro reported on 15 July that they had found BVDV in the brains of three fetuses with microcephaly.

Mayana Zatz, a geneticist and professor at the University of Sao Paulo, and her team were analysing genetic material from mothers and babies to try to explain a possible "preference" of the Zika virus for some people. She was investigating eight pairs of twins. In six cases, one twin was born with microcephaly and the other without.

Other researchers were investigating whether infection with yellow fever could offer protection against the damaging effects of the Zika virus. Kallas, however, was sceptical. He said that there were many areas with low vaccination rates against yellow fever with few cases of microcephaly.

Mayor S. Zika infection in pregnancy is linked to range of fetal abnormalities, data indicate. BMJ 2016;352:i1362doi:10.1136/bmj.i1362

2 Dyer O. US agency says Zika virus causes microcephaly. BMJ 2016;353:i2167doi:10. 1136/bmj.i2167.

3 Dyer $\mathrm{O}$. Zika virus spreads across Americas as concerns mount over birth defects. $B M J$ 2015;351:h6983doi:10.1136/bmj.h6983.

4 Centro de Operações de Emergências em Saúde Pública sobre Microcefalias. Brazil epidemiological microcephaly records. 2016. combateaedes.saude.gov.br/images/pdf/ informe_microcefalia_epidemiologico36.pdf.

Published by the BMJ Publishing Group Limited. For permission to use (where not already granted under a licence) please go to http://group.bmj.com/group/rights-licensing/ permissions 